\title{
ASPECTS OF ROMANIAN EARLY JURASSIC PALAEOBOTANY AND PALYNOLOGY. PART IV. A NEW SPECIES OF WELTRICHIA FROM ANINA
}

\author{
MIHAI E. POPA ${ }^{1}$
}

\begin{abstract}
A new species of bennettite genus Weltrichia BRAUN, Weltrichia givulescui n.sp., is defined, described and discussed. Its age is Sinemurian and it was recorded associated with Zamites aninaensis foliage from Anina, South Carpathians, Resita Basin, where these species are confined to the upper sandstone sequences of the Valea Tereziei Member, Steierdorf Formation, between the Coal seams no. 6 and 8.
\end{abstract}

Keywords: Weltrichia givulescui, Cycadeoidales, male reproductive structure, Sinemurian, Anina, South Carpathians, Reşița Basin, Romania.

\section{INTRODUCTION}

Lower Jurassic deposits of Romania yield a rich land flora, well preserved and diverse (Popa, 1998, 2000a). One of the most important Liassic plant locality (LPL) of Romania, a fossile-Lagerstatte locality is Anina (Popa, 1997), formerly known as Steierdorf, which belongs to the Getic Nappe, Reşița Basin respectively. In Anina occurs a palaeobotanical reserve confined to the southern area of the Ponor Quarry, known as the Ponor SSSI (Site of Special Scientific Interest). The Lower Jurassic deposits are included to the Steierdorf Formation (Bucur, 1991), with three members, the Dealul Budinic Member (Hettangian), a basal, coarse sequence, the Valea Mereziei Member, an unit including fine sandstones, clays, coal seams, very rich in plant fossils (Hettangian-Sinemurian) and the Uteris Member (PliensbachianToarcian), represented by black bituminous shales. Details of the litho- and phytostratigraphy of the Steierdorf Formation are discussed in detail in Popa (2000a, b).

The Valea Tereziei Member includes eight coal seams and a refractory clay bed, where the Hettangian-Sinemurian boundary is recorded (Popa, 2000a, b). Also, at the Hettangian-Sinemurian boundary is recorded a floral change, where two separate assemblages are now known to follow one after another. The first, Hettangian assemblage is marked by the Dipteridaceous fern Thaumatopteris brauniana and the second, Sinemurian assemblage, is marked by the boom of the Cycadalean species Nilssonia cf. orientalis. Details of the assemblages and their definitions are given in Popa (2000a, b). The new species of Weltrichia described in this paper is recorded from the Sinemurian deposits of the Valea Tereziei Member, from sequences overlying the $6^{\text {th }}$ Coal seam from Anina.

${ }^{1}$ University of Bucharest, Faculty of Geology and Geophysics, Laboratory of Palaeontology, 1, N. Balcescu Ave., 70111, Bucharest, Romania. E-mail: mihaip@geo.edu.ro, mihaip@math.math.unibuc.ro. 


\section{SYSTEMATICS}

Bennettite male reproductive structures were previously described in Romania from Lower Jurassic deposits of the South Carpathians and from Middle Jurassic deposits of Central Dobrogea, south-eastern Romania, together with a wide variety of foliage types. From the South Carpathians, these reproductive structures were described mainly from the Reşița Basin, the first author to approach this kind of cycadeoid organs being Krasser $(1915,1922)$. Krasser (1915) described "male Williamsonias" from Anina, as Williamsonia banatica and W. alfredi, but these species belong to the genus Weltrichia BRAUN, Williamsonia being a denomination for female reproductive structures. Langer (1947) described and figured a "neue Weltrichia-Blute" which is actually a Weltrichia banatica (Popa, 2000a). Givulescu (1990) also described two new bennettite reproductive structures from Anina, including this new taxon. Popa (1998) as well cited Weltrichia species collected from Anina, and described them in detail, together with a Williamsonia species (Popa, 2000a).

Genus Weltrichia was defined by Braun (1849) for bennettite male reproductive structures but this combination was not used widely by later authors who preferred to use the term "male Williamsonia". Nathorst (1909) and Harris (1969) showed that the denomination of Weltrichia should be used instead of that of "male Williamsonia".

\section{Class CYCADOPSIDA Order CYCADEOIDALES \\ Genus Weltrichia BRAUN emend. HARRIS 1969 Weltrichia givulescui POPA n.sp. Text-figs. 1-4, PI. I, Figs. 1-3}

1969 Williamsonia sp. HUMML, p. 349, PI. VII, Fig. 15. 1990 Weltrichia sp. (?n.sp.) GIVULESCU, p. 2. PI. 1, Fig. 1, PI. 2, Fig. 1, 2.

Holotype: fragment 1 from sample $\mathrm{P} 113 / \mathrm{C} 1 / 30 \mathrm{~A}$.

Paratypes: fragment 1 from sample P113/C1/30B and fragment 1 from sample UEB1.

Repository: University of Bucharest, Faculty of Geology and Geophysics, Laboratory of Palaeontology, in the Popa Palaeobotanical collection.

Type locality: Anina, Caraş-Severin County, Romania.

Stratigraphic horizon: Steierdorf Formation, within the upper, Sinemurian sequence of the Valea Tereziei Member, mainly within the roofs of the Coal seams nos. 6 and 7.

Etymology: Weltrichia givulescui, in honor of Professor Dr. Razvan Givulescu, Corresponding member of the Romanian Academy, as a homage of his brilliant contributions in the fields of Palaeobotany and Geology, celebrating his $80^{\text {th }}$ anniversary. 


\section{Diagnosis}

Bennettitalean male reproductive structure with 16 radial microsporophylls (rays) and a central cup, deeply depressed. The sporophylls have a longitudinal rib on abaxial and adaxial sides, entire margins, acute apices, they are fibrous and thick, and each of them is continued centripetally with an appendage that overlaps the adaxial, inner surface of the central cup. The central cup is covered adaxially by small pustules, possibly attractant bodies.

\section{Description}

Male, reproductive, cup shaped structures with radially disposed, flattened and fibrous microsporophylls (rays) having a longitudinal, an adaxial and an abaxial rib. This is why the sporophylls appear to be rhombic in cross section. Substance of sporophyll lamina very thick. Sporophylls are usually 16 per whorl and they are adnate in the center of the cup, where the structure is strongly depressed (PI. I, Figs. 1, 3). They are inserted radially to the cup, sometimes slightly overlapping to their bases, although they are always attached in the same plane. Apices of sporophylls are acute. The external diameter is $80-90 \mathrm{~mm}$, the central, adnate area's diameter is $30-40 \mathrm{~mm}$, the length of the free part of sporophylls is $40-50 \mathrm{~mm}$ and their width is $7-10 \mathrm{~mm}$. The external surface of the cup and sporophylls is smooth, while the internal surface of the cup is slightly granulated, indicating the occurrence of possible attractant bodies (Text-figs. 2, 4, PI. I, Fig. 3). Each sporophyll is continued towards the centre of the cup by a short, free, centripetal appendage (sterile inner scales), overlapping the inner surface (Text-figs. 1, 3, 4, Pl. I, Fig. 1). Each appendage is $2-3 \mathrm{~mm}$ wide and $7-10 \mathrm{~mm}$ long. The adaxial surface of the sporophylls is rather smooth, without preserving polliniferous sacs or even their clear insertion. No cuticles or in situ pollen were extracted.

\section{Discussion}

In the depressed area of the structure, no indication of any ovulate cone exists, so no evidence for a possible Williamsonia exists at all. The recently collected material (in 1994, 1995, 1997) from Anina, shows undoubtedly the same species, a clear Weltrichia taxon. Harris (1969) showed the validity of Weltrichia, instead of "male Williamsonia", after a long period of time when the last denomination was largely used.

W. givulescui was described by Humml (1969) from Anina as Williamsonia $\mathrm{sp}$., on material collected from the roof of the Coal seam no. 7, with the same phytostratigraphic position as the material described here, his data matching again with the data presented here. His description is accurate but incomplete, his material being not so well preserved.

This species was previously described also by Răzvan Givulescu (1990) as Weltrichia sp. (?n.sp.), also from Anina locality. He intuited that this is probably a new species but he did not name it consequently. Actually, his material stored within the Laboratory of Palaeontology, Babeş-Bolyai University of Cluj-Napoca, lacks any of the centripetal appendages or pollen sacs, making difficult to assess the material to a new taxon.

The closest Weltrichia species is Weltrichia setosa NATHORST emend. HARRIS 1969. This species resembles $W$. givulescui as it is the only Weltrichia species that has centipetal appendages, but these appendages are covered by long hairs, which is not the case of our new species. Also, the number of sporophylls 
and of the centripetal appendages is far higher than in W. givulescui, in W. setosa each sporophyll tending to have two appendages. Moreover, $W$. setosa is associated with Otozamites beani, although Harris (1969) did not assign it surely to this foliage.

Similarities are shared with Weltrichia alfredi KRASSER emend. HARRIS 1969, especially in sporophylls ornamentation, but $W$. alfredi has less sporophylls per cup and no attractant bodies inside the central area. $W$. alfredi is always associated with Ptilophyllum maculatum foliage and probably it is the reproductive structure of the plant bearing these leaves.

Another similar reproductive structure that was also described from Anina and with the same stratigraphic range is Weltrichia banatica KRASSER emend. GIVULESCU 1990. But this species has different shape of sporophylls, and their number is much higher (21-22). W. banatica is intimately associated with Zamites schmiedelii foliage and probably it belongs to this species.

The invariable occurrence of $W$. givulescui especially with Zamites aninaensis, but also with $Z$. schmiedelii and $Z$. andraeanus foliage suggests that this structure belongs to one of these plants, most probably to $Z$. aninaensis (PI. I, Fig. 4).

Interesting to note is the role of the centripetal appendages over the central cup. There is no doubt that Weltrichia type structures, as all the other cycadeoid reproductive structures evolved in intimate connection with insect behavior, and that a strong coevolution existed between the bennettites and insects. This coevolution finally had as an effect the emergence of angiosperms (at least part of them as they are a polyphyletic group) during the Late Jurassic times or even earlier. In Weltrichia givulescui, the role of the centripetal appendages might have been that of increasing the contact surface with the insects or that of supplementary protection of attractants occurring inside the cup. Trapping insects temporary or definitively inside the cup may have also been an aim for these centripetal appendages but it looks more improbable than the other roles.

\section{Preservation}

The material is compressed, with the lamina of the microsporophylls often well preserved. The preservation is rather good, with structures preserved transversally (PI. I, Figs.1, 3) or longitudinally (PI. I, Fig. 2), in spite of polliniferous sacs lacking.

\section{Occurrence and phytostratigraphy}

The stratigraphic position of $W$. givulescui is always above the Coal seam No. 5 , in all Anina coalfields. Usually, it can be found within the roofs of the $6^{\text {th }}$ or $7^{\text {th }}$ Coal seams in Anina area, especially for the Northern Coalfields (Anina, Zona Nouă and Brădet Coalfields). It is a typical Sinemurian taxon and the reproductive structure of a Sinemurian coal generator.

\section{Conclusions}

Weltrichia givulescui is a new species of male bennettite reproductive structure from Anina, Sinemurian in age, intimately associated with Zamites aninaensis foliage and it is probably the reproductive structure of the plant that was bearing this foliage. 


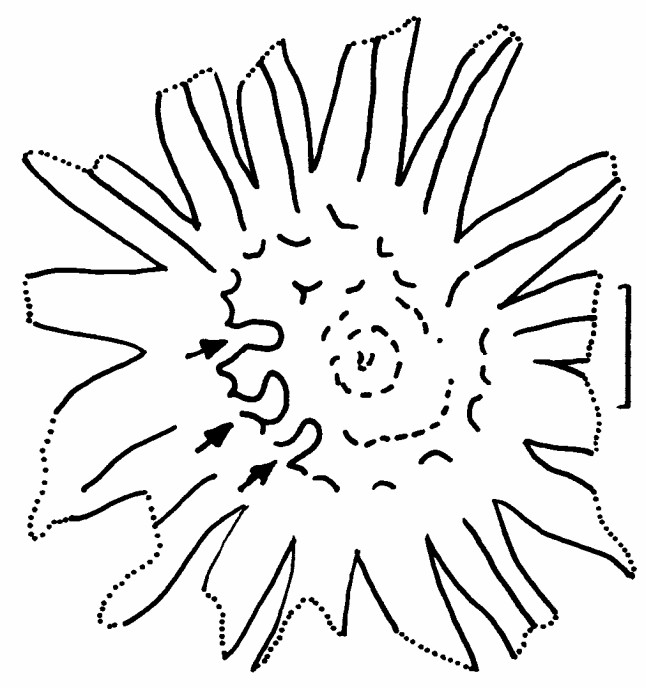

Text-fig. 1. Weltrichia givulescui n.sp., holotype, P113/C1/30A/Fr.1, preserved transversally. Arrows indicate the presence of appendages. Scale bar: $1 \mathrm{~cm}$.

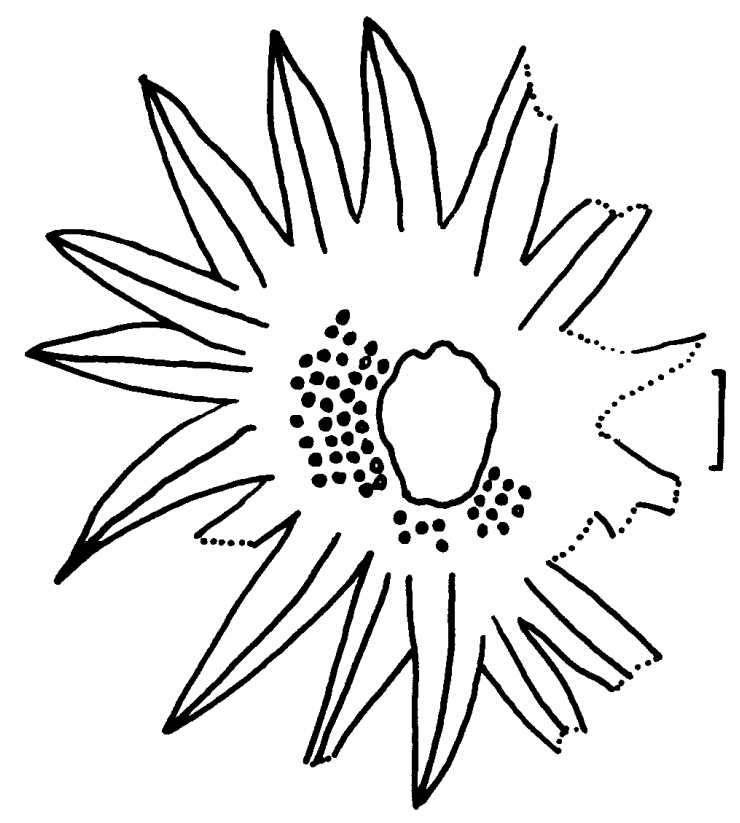

Text-fig. 2. W. givulescui n.sp., paratype, UEB1/Fr.1, preserved transversally. Scale bar: $1 \mathrm{~cm}$. 


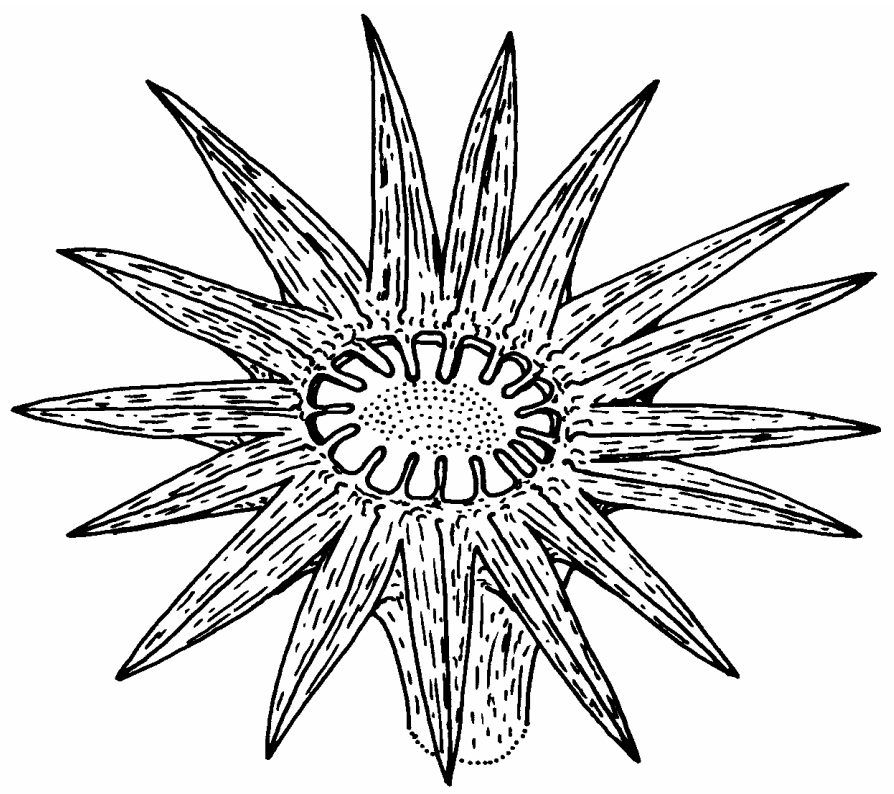

Text-fig. 3. Reconstruction of a ripen $W$. givulescui n.sp., with the insertion points of the polliniferous sacs not figured as they could not be found due to preservation.

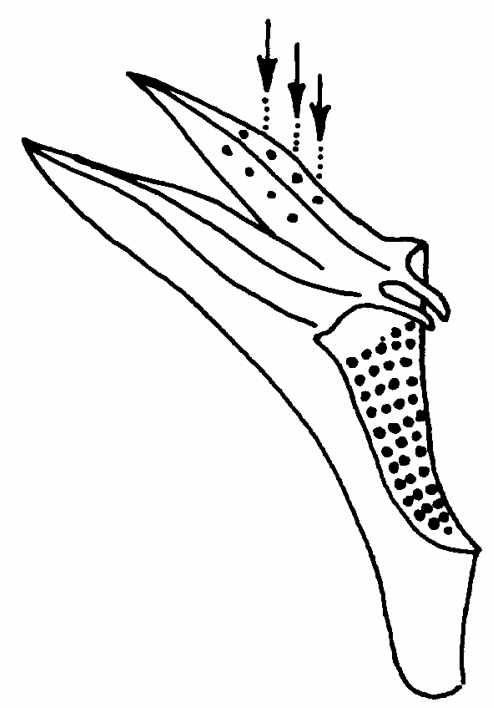

Text-fig. 4. Axial section through the central cup of $W$. givulescui n.sp., showing the internal bodies, appendages and sporophylls. Arrows indicate the possible position of the polliniferous sacs. 


\section{Acknowledgements}

I wish to thank to Dr. Valentin Popescu (Ecological University, Bucharest), Dr. lustinian Petrescu and Dr. Ioan I. Bucur (Babeş-Bolyai University, Cluj-Napoca) for their kind help. This paper is part of a larger work presented by the author in Quinhuangdao, China, to the VI-th IOP Conference, in August 2000. Financial support was provided by the Romanian Academy research Grant no. 5003/1999.

\section{REFERENCES}

Braun, F. (1849), Weltrichia, eine neue Gattung fossiler Rhyzantheen, Flora, 32:705-712.

Bucur, I.I. (1991), Proposition pour une nomeclature lithostratigraphique formelle des depots paleozoiques et mesozoiques de la zone de Resita-Moldova Noua (Carpathes meridionales, Roumanie), Studia Univ. Babeş-Bolyai, Geologie, XXXVI/2: 3-14.

Krasser, F. (1915), Mannlische Williamsonien aus dem Sandsteinschiefer des unteren Lias von Steierdorf im Banat. Denkschrisften der mathem.-naturw. Klasse, 93(107): 1-18.

Krasser, F. (1922) Zur Kenntnis einiger fossiler Floren des unteren Lias den Sukzessionstaaten von Ostereich-Ungarn. Sitzungsberichte d. mathem.-naturw. KI., 1: 345-373.

Langer, J. (1947), Uber einige Stucke der Liasflora von Steierdorf und der Keuperflora von Lunz. Jahrbuch der Geologischen Bundesanstalt, XC(1-2): 22-33.

Harris, T.M. (1969), The Yorkshire Jurassic Flora. Part 3: Bennettitales, 3, London, 186 pp.

Givulescu, R. (1990), Zwei neue Bennettitenblutten aus dem Unteren Lias von Anina (Banat, Rumanien). Documenta Naturae, 59(2): 1-7.

Humml, H. (1969) Contributii la flora fosila a Liasicului inferior de la Steierdorf-Anina. Stud. Cerc. Geol. Geofiz. Geogr. (Geol.), 14(2): 385-404.

Nathorst, A. (1909), Paleobotanische Mitteilungen, no. 8. Uber Williamsonia, Wielandia, Cycadocephalus und Weltrichia. Kongl. Svenska Vetenskaps Akademiens Handlingar, 45(4).

Popa, M.E. (1997), Corystospermal pteridosperms in the Liassic continental deposits of Romania. Acta Palaeontologica Romaniae(1): 81-87.

Popa, M.E. (1998), The Liassic continental flora of Romania: Systematics, Stratigraphy and Paleoecology. Acta Horti Botanici Bucurestiensis, (1997-1998): 177-184.

Popa, M.E. (2000a), Early Jurassic land flora of the Getic Nappe, University of Bucharest, Bucharest, $\mathrm{PhD}$ thesis, $258 \mathrm{pp}$.

Popa, M.E. (2000b), Aspects of Romanian Early Jurassic Palaeobotany and Palynology. Part III. Phytostratigraphy of the Getic Nappe. Acta Palaeontologica Romaniae, 2: 377-386.

Plate I

\section{PLATE CAPTIONS}

Fig. 1. Weltrichia givulescui n.sp., holotype, P113/C1/30A/Fr.1, preserved transversally. Fig. 2. W. givulescui n.sp., paratype, P113/C1/30B/Fr.1, preserved longitudinally. Fig. 3. W. givulescui n.sp., paratype, UEB1/Fr.1, preserved transversally. Fig. 4. Zamites aninaensis, P113/C1/48/Fr.1. All scale bars: $1 \mathrm{~cm}$. 
PLATE I
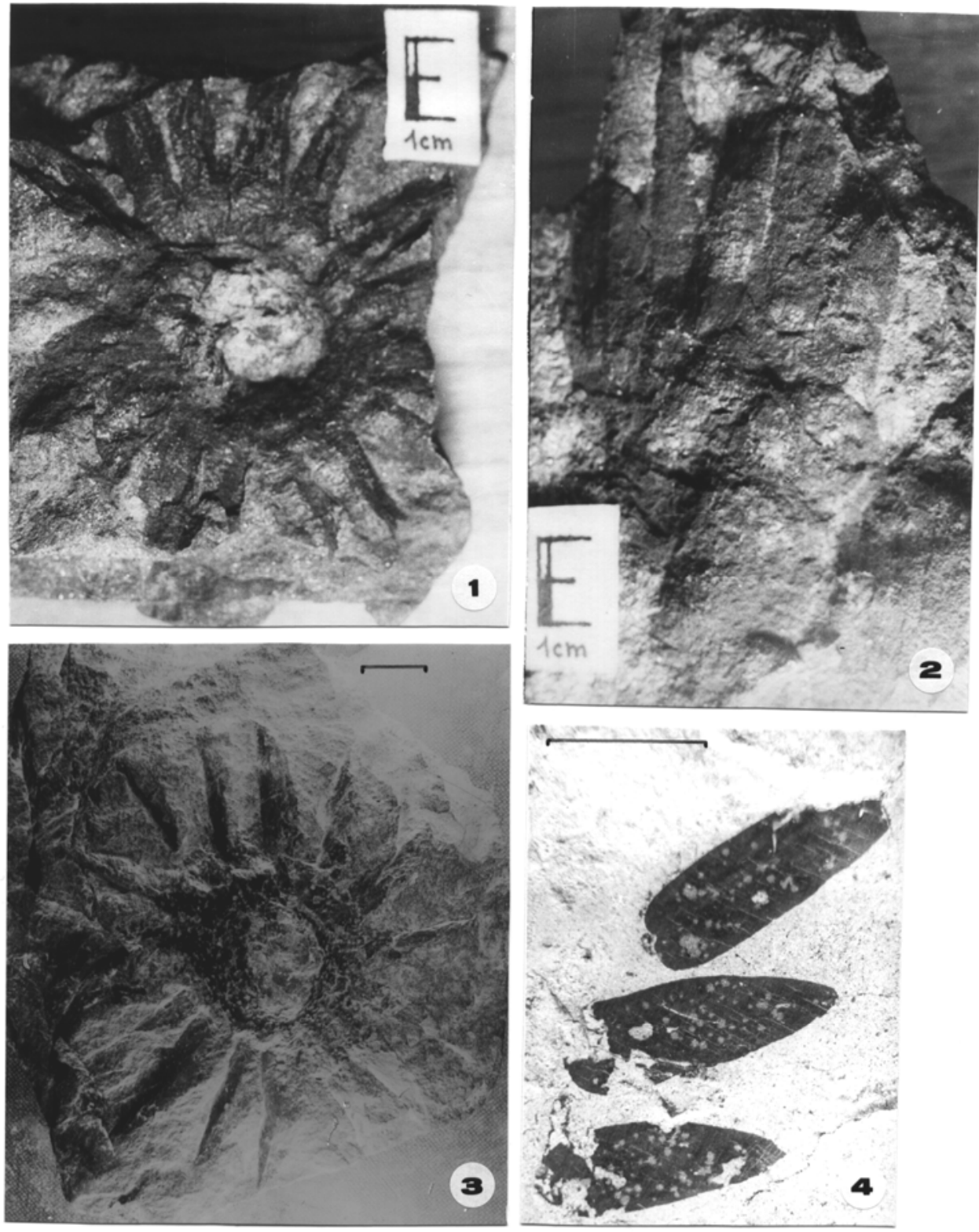